\title{
Dose-dependent effect of resveratrol on proliferation and apoptosis in endothelial and tumor cell cultures
}

\author{
Béla Szende ${ }^{1,4}$, Ernõ Tyihák ${ }^{2}$ and \\ Zsuzsa Király-Véghely ${ }^{3}$ \\ ${ }^{1} 1^{\text {st }}$ Institute of Pathology and Experimental Cancer Research, \\ Semmelweis University, Budapest, Hungary \\ ${ }^{2}$ Plant Protection Institute, Hungarian Academy of Sciences, \\ Budapest, Hungary \\ ${ }^{3}$ Research Institute for Viticulture and Enology, Experimental Wine \\ Cellar, Ministry of Agriculture, Budapest, Hungary \\ ${ }^{4}$ Corresponding author: Tel, +36-1-266-0451; Fax, +36-1-317-1074; \\ E-mail: bszende@korb1.sote.hu
}

Accepted 22 June 2000

Abbreviations: LDL, low density lipoprotein

\begin{abstract}
Experimental data suggest that Resveratrol, a compound found in grapes and other fruits may influence cell proliferation and apoptosis. The aim of our experiments was to study the effect of Resveratrol on tumor cell cultures and an endothelial cell culture in order to examine the effect of various doses of this compound on active cell death and cell proliferation. Human tumor (HT-29, SW-620, HT-1080) and endothelial (HUV-EC-C) cells were treated with various doses of $(0.1$ to $100.0 \mu \mathrm{g} / \mathrm{ml})$ Resveratrol in vitro. Cell number, apoptotic and mitotic index was measured 24, 48 and $72 \mathrm{~h}$ after treatment. Low doses $(0.1-1.0 \mu \mathrm{g} / \mathrm{ml})$ of Resveratrol enhance cell proliferation, higher doses $(\mathbf{1 0 . 0 - 1 0 0 . 0} \mu \mathrm{g} / \mathrm{ml})$ induce apoptosis and decrease mitotic activity, which is reflected in changes of cell number. Resveratrol influences dose dependently the proliferative and apoptotic activity of human tumor and endothelial cells. The possible role of formaldehyde in the mechanism of action of Resveratrol is discussed.
\end{abstract}

Keywords: Resveratrol, apoptosis, mitosis

\section{Introduction}

Resveratrol, 3,5,4'-trihydroxystilbene, which exists in both cis and trans configurations, occurs naturally in grapes (Langcake et al., 1976) and grape products (Siemann and Creasy 1992), as well as in other plant species [e.g.
Arachis hypogea (Ingham et al., 1976), Polygonum cuspidatum (Arichi et al., 1982), Yucca schidigera (Uenobe et al., 1997)]. The biological function of transResveratrol is thought to be the protection of plants from environmental stress and fungal attack (Soleas et al., 1997).

Resveratrol intake has been associated with a moderate consumption of red wine and has been suggested to play a role in the reduction of risk of coronary heart disease (Pace-Asciak et al., 1995). This stylbene derivative has been shown to protect human (low density lipoprotein) LDL against copper-catalyzed oxidation in vitro (Franke et al., 1993) and to inhibit human platelet aggregation and thromboxane B2 synthesis (Bertelli et al., 1995; Pace-Asciak et al., 1995). An in vivo study demonstrated that daily consumption of red wine for 2 weeks reduced the susceptibility of LDL to lipid peroxidation, whereas white wine consumption showed the opposite effect (Fuhrman et al., 1995; Nigdikar et al., 1998). Although Resveratrol is a powerful antioxidant in vitro, it doesn't prevent the oxidation of plasma lipids in healthy rats (Turrens et al., 1997). These controversial results demand a dose-dependent study of the action of Resveratrol using endothelial cells.

Resveratrol has been shown to have a cancer preventive activity in tumor initiation, promotion and progression (Jang et al., 1997). Resveratrol has a direct antiproliferative effect on human breast epithelial cells (Mgbonyevi et al., 1998). Synthetic Resveratrol in concentrations equivalent to those in red wine inhibit proliferation of oral cancer cells (Goldberg et al., 1995; Romeroperez et al., 1996; ElAttor et al., 1999). Resveratrol induced apoptotic cell death in HL60 leukemia cells as well as in T470 breast carcinoma cells (Clement et al., 1998). According to recent investigations, Resveratrol is an effective inhibitor of cell growth in general, triggers partial arrest of $\mathrm{G} 1 / \mathrm{S}$ transition in prostate cancer cell lines and induces apoptosis (Hsieh et al., 1999).

The present paper was designed to study the dosedependent effect of synthetic Resveratrol on proliferation and apoptosis in endothelial and tumor cells in culture.

\section{Materials and Methods}

Various human cell lines HT-29 human colon carcinoma (ATCC HTB-38), SW-620 human colon carcinoma (ATCC CCL-227), HT-1080 human fibrosarcoma (ATCC CLL121), HUV-EC-C human endothelial (ATCC CRL-1730) 
cells were cultured in 6 well and 24 well Grainer plates (Kremsmünster, Austria) using RPMI supplemented with $10 \%$ fetal calf serum (Protein Biochemical Ltd., Gödöllõ, Hungary), in a humidified $\mathrm{CO}_{2}$ incubator. The number of cells at plating was $10^{5} / \mathrm{ml}$. Triplicate samples of cultured cells were treated with 1.0-10.0 $100.0 \mu \mathrm{g} / \mathrm{ml}$ Resveratrol (Sigma), $24 \mathrm{~h}$ after plating. In case of HUV-EC-C cells, $0.1 \mu \mathrm{g} / \mathrm{ml}$ Resveratrol treatment was also performed. Treatment was performed in serum-free RPMI and medium was not changed further during the experiment. Three samples of cells, which were cultured in 24-well plates, were used for cell count. Cells were detached by rinsing after trypsinisation $(0.25 \%)$ and counted in a Buerker chambre. Three samples of cultures, which were maintained and treated in 6 well plates, were used for morphological studies. For this purpose, cover slips were posited on the bottom of the wells. The cultured cells growing on the cover slips were fixed with methanol and stained with hematoxylin and eosin (HE). Samples were taken for cell count (all types of cultures) and for counting apoptosis and mitosis (HT-29 HT-1080 and HUVEC-C cultures) 24 and $48 \mathrm{~h}$ after Resveratrol treatment.

According to the criteria of Wyllie (1987) mitotic and apoptotic figures were counted in 2000 cells, the mitotic and apoptotic index were given as percent. Statistical analysis was performed using Student's t-test.

\section{Results}

Our results show dose-dependent effect on normal endo- thelial cells in culture. Figure 1 illustrates that the cell number of HUV-EC-C cells in culture is decreased drastically at 10 and maroly $100 \mu \mathrm{g} / \mathrm{ml}$ concentration of transResveratrol for 24 to $48 \mathrm{~h}$. One $\mu \mathrm{g} / \mathrm{ml}$ of resveratrol exerted a slight antiproliferative effect. However, a significant, well-measurable proliferation promoting effect on HUV-EC-C cells in culture for 24 to $48 \mathrm{~h}$ was detected if the amount of Resveratrol applied was very small $(0.1 \mu \mathrm{g} / \mathrm{ml})$. Table 1 shows the effect of resveratrol on the mitotic and apoptotic index of HUV-EC-C endothelial cell culture. Mitotic index is practically zero at high doses of Resveratrol and at the small dose (0.1 $\mu \mathrm{g} / \mathrm{ml}$ ) the mitotic index exceeded the control value for 24 to $48 \mathrm{~h}$. The apoptotic index decreased with the decrease of the concentration of resveratrol and this change was near to zero at the $0.1 \mu \mathrm{g} / \mathrm{ml}$ dose.

Figure 2, 3 and 4 demonstrate the response of various human tumor cells as SW-620, HT-29 and HT-1080 to the administration of various doses of resveratrol. Hundred $\mu \mathrm{g} / \mathrm{ml}$ treatment caused marked decrease in

Table 1. Effect of resveratrol on the apoptotic and mitotic index of HUVEC-C Endothelial cell culture

\begin{tabular}{ccccc}
\hline & \multicolumn{2}{c}{ Apoptosis } & \multicolumn{2}{c}{ Mitosis } \\
\hline & $24 \mathrm{~h}$ & $48 \mathrm{~h}$ & $24 \mathrm{~h}$ & $48 \mathrm{~h}$ \\
\hline Control & 3 & 2 & 5 & 6 \\
$0.1 \mu \mathrm{g} / \mathrm{ml}$ & 0 & 1 & 6 & 7 \\
$1.0 \mu \mathrm{g} / \mathrm{ml}$ & 1 & 2 & 6 & 7 \\
$10 \mu \mathrm{g} / \mathrm{ml}$ & 4 & 5 & 0 & 0 \\
$100 \mu \mathrm{g} / \mathrm{ml}$ & 100 & 100 & 0 & 0 \\
\hline
\end{tabular}

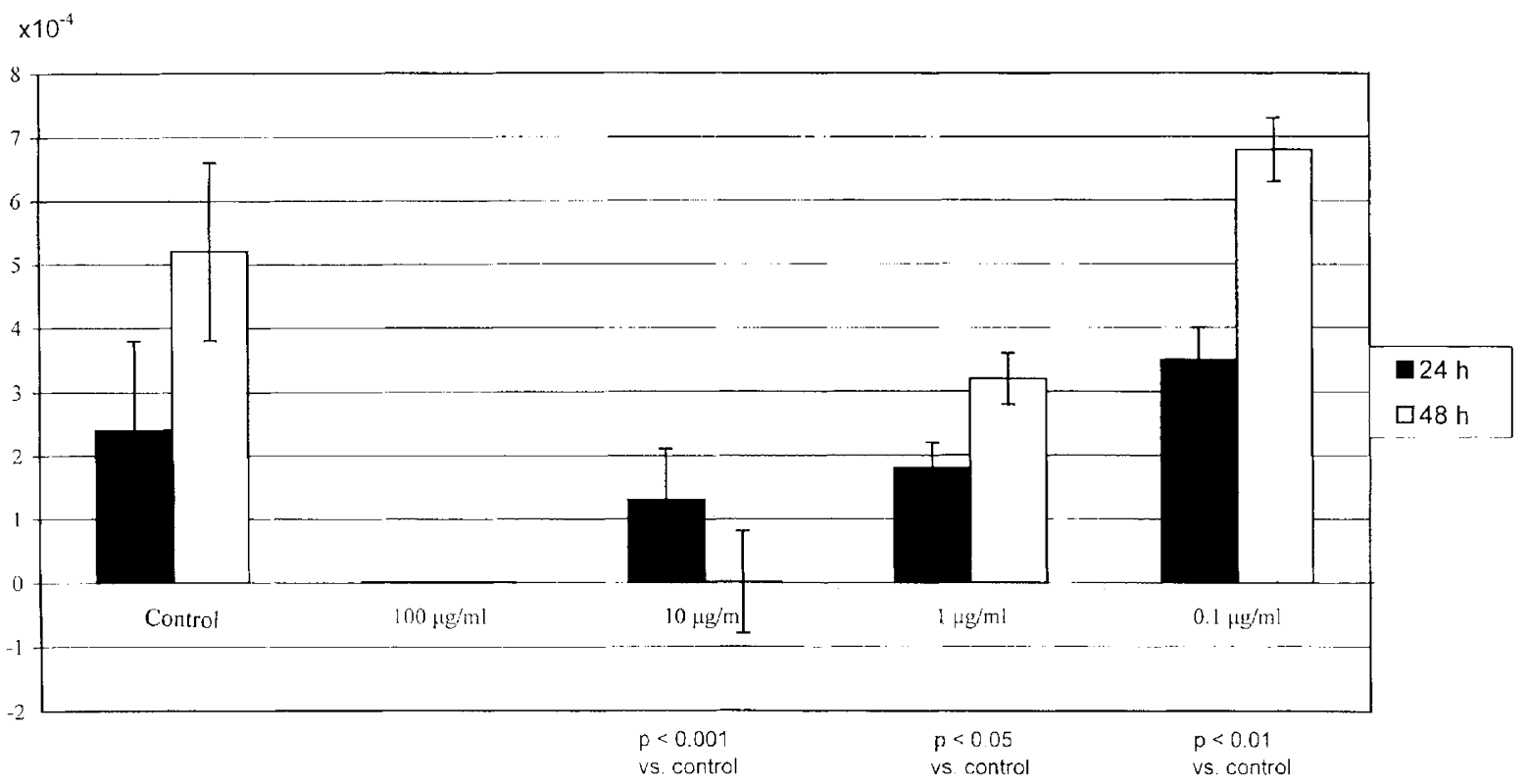

Figure 1. Effect of reserveratol on the proliferation of HUV-EC-C cells. HUV-EC-C human endothelial cells $\left(10^{5} \mathrm{cells} / \mathrm{ml}\right)$ were plated and cultured in 24 well Grainer plates as described in the Methods. Triplicate samples of cells were treated with $0.1,1,10,100 \mu \mathrm{g} / \mathrm{ml}$ reserveratol for 24 (open bar) to 48 (solid bar) $\mathrm{h}$ in a serum free RPMI. The Control was without reserveratol. Cells were counted in Buerker chamber after trypsinization. 


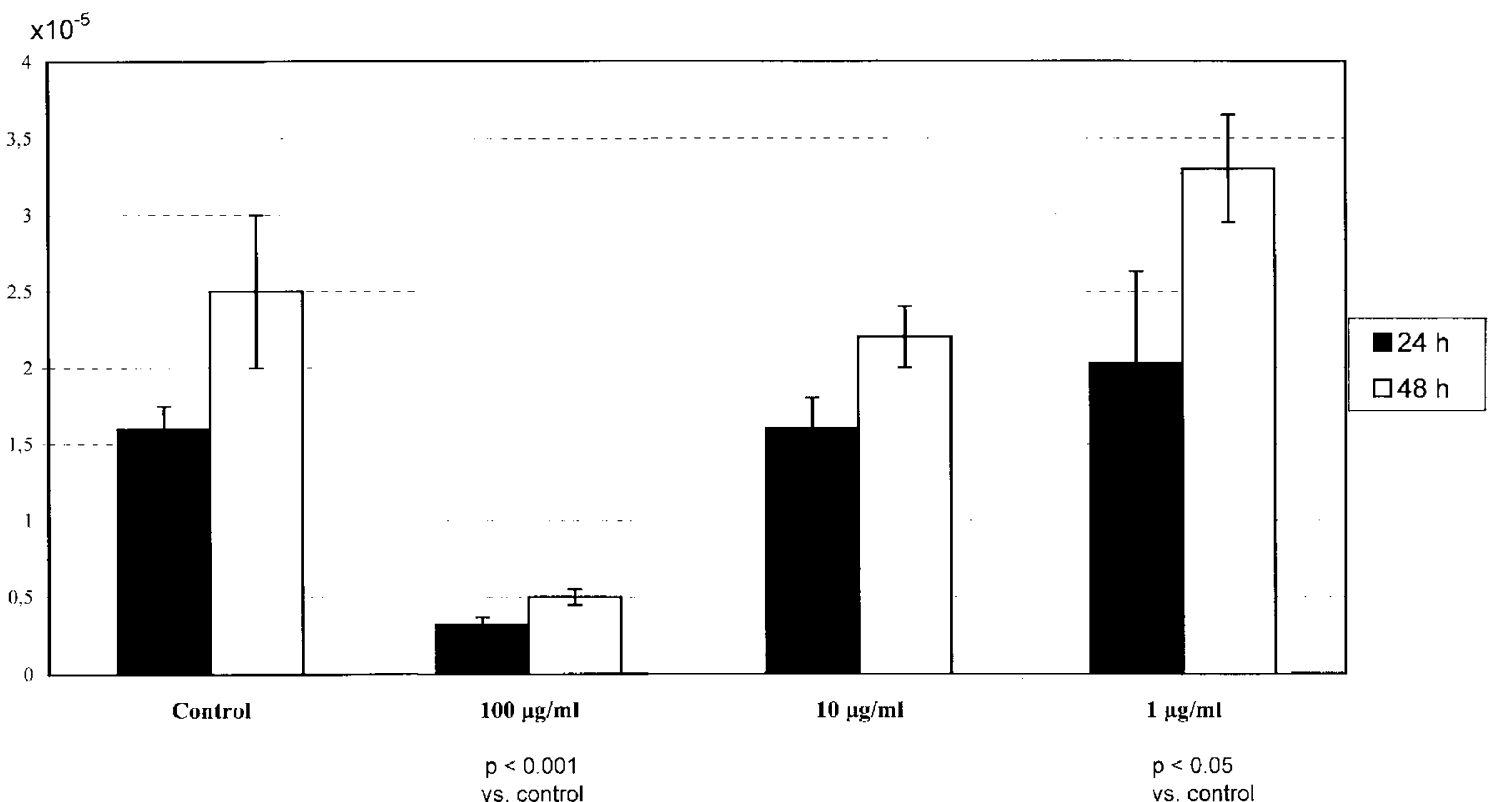

Figure 2. Effect of reseveratol on the proliferation of SW-620 cells. SW-620 human colon carcinoma cells $\left(10^{5} \mathrm{cells} / \mathrm{ml}\right)$ were plated and cultured in 24 well Grainer plates as described in the Methods. Triplicate samples of cells were treated with 1, 10,100 $\mu \mathrm{g} / \mathrm{ml}$ Reserveratol for 24 (open bar) to 48 (solid bar) $\mathrm{h}$ in a serum free RPMI. The control was without reserveratol. Cells were counted in Buerker chamber after trypsinization.

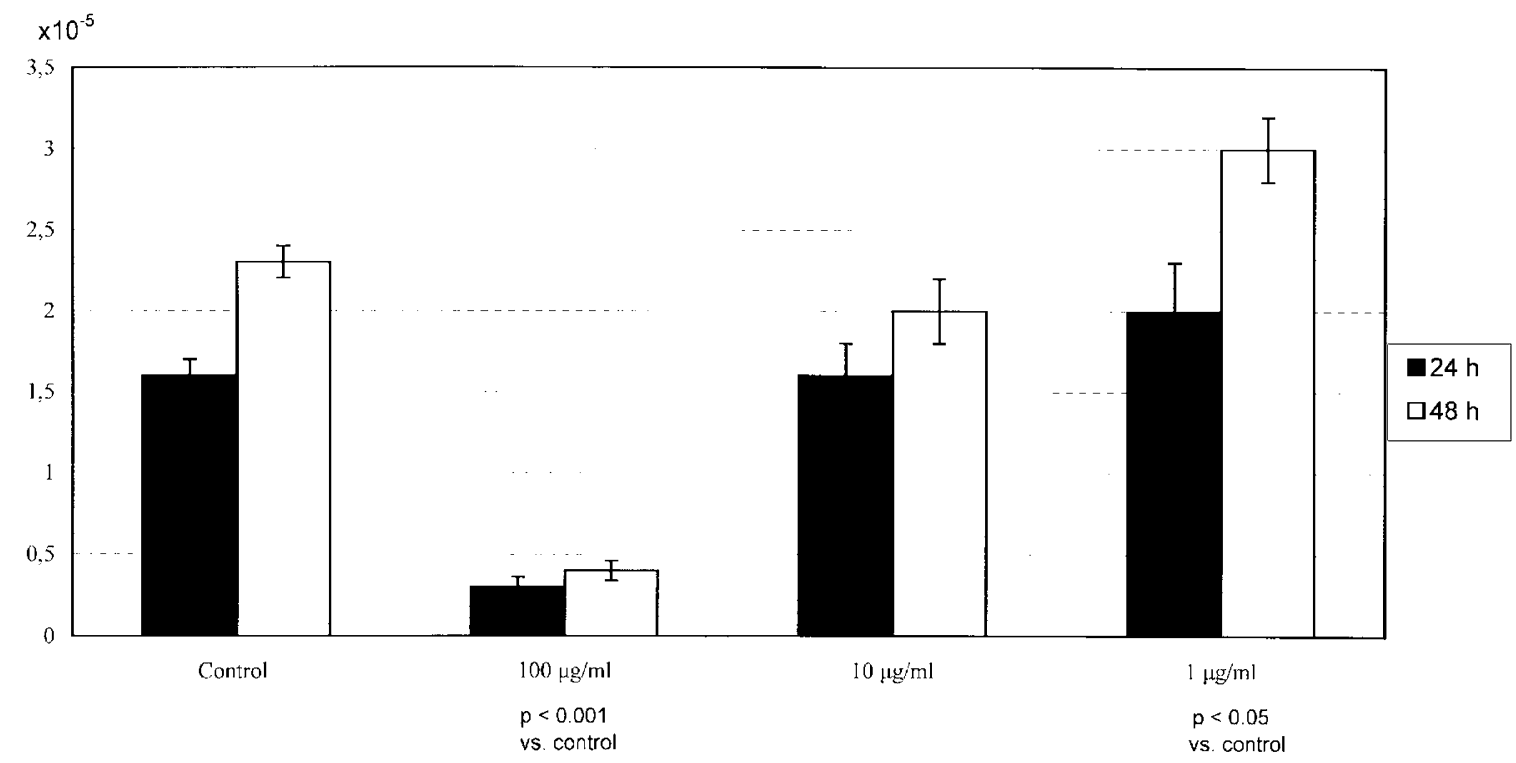

Figure 3. Effect of Reserveratol on the proliferation of HT-29 cells. HT-29 human colon carcinoma cells $\left(10^{5} \mathrm{cells} / \mathrm{ml}\right)$ were plated and cultured in 24 well Grainer plates as described in the Methods. Triplicate samples of cells were treated with 1, 10,100 $\mu \mathrm{g} / \mathrm{ml}$ Reserveratol for 24 (open bar) to 48 (solid bar) $\mathrm{h}$ in a serum free RPMI. The Control was without Reserveratol. Cells were counted in Buerker chamber after trypsinization.

cell number for 24 and $48 \mathrm{~h}$. Administration of $10 \mu \mathrm{g} / \mathrm{ml}$ was less effective in SW-620, HT-29 and HT-1080 cultures (at $48 \mathrm{~h}$ the normal HUV-EC-C cells were totally eradicated Figure 1). Proliferation of the tumor cell lines (SW-620, HT-29 and HT-1080) were stimulated by 1.0 $\mu \mathrm{g} / \mathrm{ml}$ in various degrees. Table 2,3 show apoptotic and mitotic activity of HT-29 and HT-1080 tumor cell cultures, respectively. Mitotic activity was blocked by
$100 \mu \mathrm{g} / \mathrm{ml}$ resveratrol in both cultures. Decrease or blockade of mitotic activity was observed after $10 \mu \mathrm{g} / \mathrm{ml}$ resveratrol and slight or no change in mitotic activity was found after $1.0 \mu \mathrm{g} / \mathrm{ml}$ resveratrol. Apoptotic activity was strongly enhanced by $100 \mu \mathrm{g} / \mathrm{ml}$ of resveratrol in all tumor cell cultures. Ten $\mu \mathrm{g} / \mathrm{ml}$ of resveratrol caused a slight increase of apoptotic activity and $1 \mu \mathrm{g} / \mathrm{ml}$ did not change or decrease the apoptotic index. 


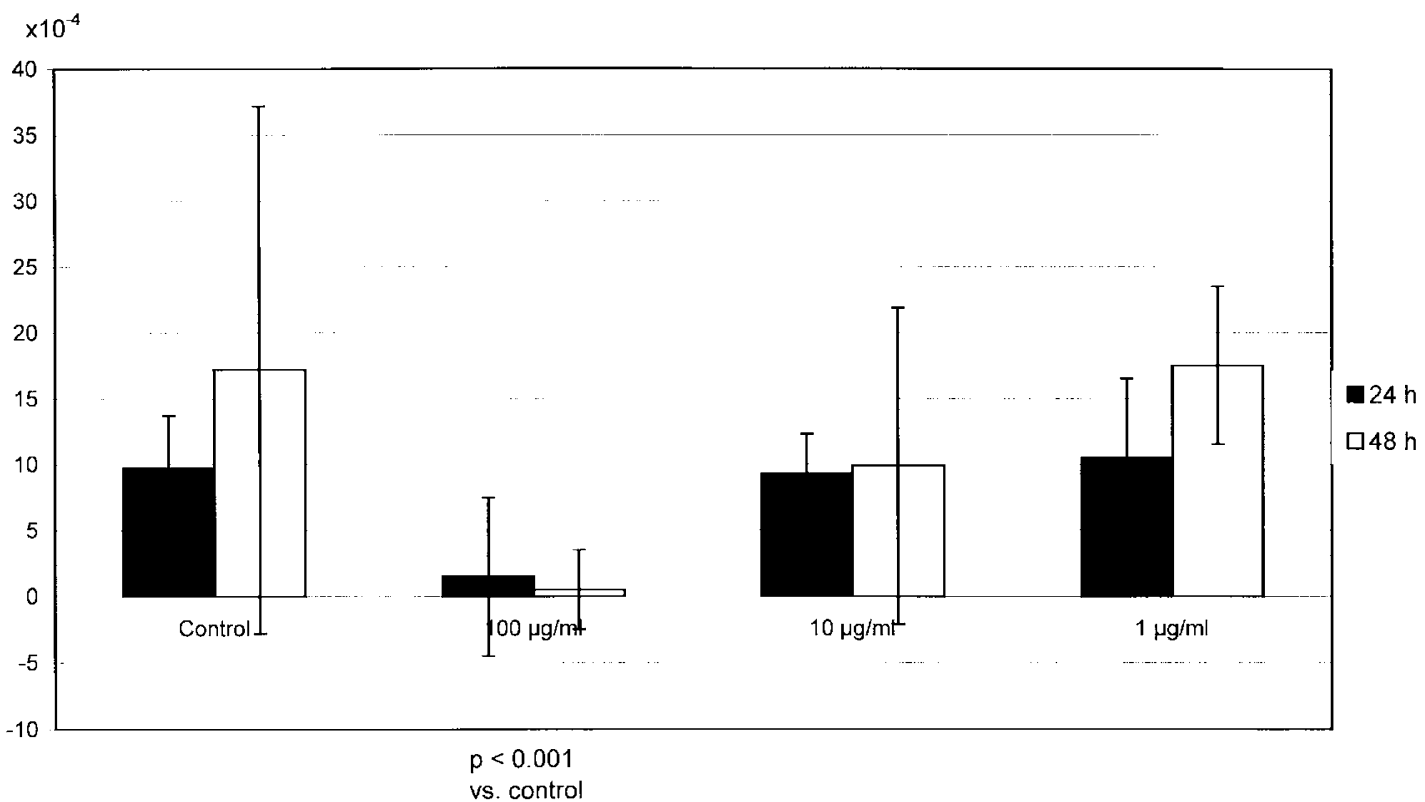

Figure 4. Effect of reserveratol on the proliferation of HT-1080 cells. HT-1080 human fibrosarcoma cells $\left(10^{5} \mathrm{cells} / \mathrm{ml}\right)$ were plated and cultured in 24 well Grainer plates as described in the Methods. Triplicate samples of cells were treated with 1, 10,100 $\mu \mathrm{g} / \mathrm{ml}$ Reserveratol for 24 (open bar) to 48 (solid bar) $\mathrm{h}$ in a serum free RPMI. The control was without Reserveratol. Cells were counted in Buerker chamber after trypsinization.

Table 2. Effect of resveratrol on the apoptotic and mitotic index of HT-29 cell culture

\begin{tabular}{ccccc}
\hline & \multicolumn{2}{c}{ Apoptosis } & \multicolumn{2}{c}{ Mitosis } \\
\cline { 2 - 5 } & $24 \mathrm{~h}$ & $48 \mathrm{~h}$ & $24 \mathrm{~h}$ & $48 \mathrm{~h}$ \\
\hline Control & 3 & 2 & 3 & 3 \\
$1 \mu \mathrm{g} / \mathrm{ml}$ & 2 & 2 & 4 & 5 \\
$10 \mu \mathrm{g} / \mathrm{ml}$ & 22 & 30 & 2 & 1 \\
$100 \mu \mathrm{g} / \mathrm{ml}$ & 75 & 75 & 0 & 0 \\
\hline
\end{tabular}

Table 3. Effect of resveratrol on the apoptotic and mitotic index of HT1080 cell culture

\begin{tabular}{ccccc}
\hline & \multicolumn{2}{c}{ Apoptosis } & \multicolumn{2}{c}{ Mitosis } \\
\cline { 2 - 5 } & $24 \mathrm{~h}$ & $48 \mathrm{~h}$ & $24 \mathrm{~h}$ & $48 \mathrm{~h}$ \\
\hline Control & 1 & 1 & 4 & 5 \\
$1 \mu \mathrm{g} / \mathrm{ml}$ & 2 & 2 & 2 & 5 \\
$10 \mu \mathrm{g} / \mathrm{ml}$ & 2 & 8 & 0 & 1 \\
$100 \mu \mathrm{g} / \mathrm{ml}$ & 20 & 80 & 0 & 0 \\
\hline
\end{tabular}

\section{Discussion}

A growing body of literature indicates that Resveratrol, a plant constituent enriched in the skin of blue grapes (Kiraly-Veghely et al., 1998), is one of the promising agents for the prevention of heart disease (Frankel et al., 1993; Pendurthi et al., 1999), cancer (Jang et al., 1997; Clement et al., 1998; ElAttor et al., 1999) and inflammatory (Goldberg et al., 1997) diseases.

We demonstrated that Resveratrol has a dose-depen- dent effect on mitotic and apoptotic activity of endothelial and tumor cell lines. These results partly support earlier similar observations regarding inhibition of cellproliferation. It seems, however, that the cell-proliferation promoting activity of Resveratrol at small concentrations $(0.1$ to $1.0 \mu \mathrm{g} / \mathrm{ml})$ is not negligeble.

It is important to notice that diverse activities of resveratrol are dose-dependent. For instance we demonstrated that resveratrol induced apoptosis in the same concentration range that inhibited cell proliferation. The induction of apoptosis is a possible explanation for the antiproliferative effect of resveratrol (Huang et al., 1999).

Some conceptions are known about the mechanism of action of resveratrol. Similarly to other polyphenols Resveratrol exerts an antioxidant effect (Frankel et al., 1993; Miller et al., 1995). This stylbene derivative has a characteristic double bond and the phenolic hydroxyl groups generate electron withdrawal. In addition Resveratrol as an antioxidant is a $\mathrm{H}$-donor molecule. These characteristics of Resveratrol favor its reactivity with formaldehyde ( $\mathrm{HCHO}$ ) (Tyihak et al., 1998). Our preliminary observations suggest that trans-resveratrol is a natural concentration-dependent $\mathrm{HCHO}$-capturing molecule. Several hydroxymethylated derivatives from the reaction mixture of resveratrol and diluted formaldehyde solution were isolated and identified (Tyihak et al., 1998). It seems that resveratrol facilitates the elimination (collection) of uncontrolled $\mathrm{HCHO}$ from tissues. The first step in the elimination of $\mathrm{HCHO}$ with resveratrol may lead to the formation of reaction products (hydroxymethyl derivatives) between resveratrol and $\mathrm{HCHO}$ 
which may promote apoptotic activity (Szende et al., 1999). HCHO mobilization from hydroxymethyl groups due to the $\mathrm{H}$-donor potential of resveratrol may be the basis of the diverse biological effects of transResveratrol.

\section{References}

Arichi, H., Kimura, Y., Okuda, H., Baba, K., Kozawa, M. and Arichi, S. (1982) Effects of stylbene compounds of the roots of Polygonum cuspidatum Sieb. et Zucc. on lipid metabolism. Chem. Pharm. Bull. 30: 1766-1770

Bertelli, A. A. E., Giovannini, L., Giannessi, D., Migliori, M., Bernini, W., Fregoni, M. and Bertelli, A. (1995) Antiplatelet activity of synthetic and natural Resveratrol in red wine. Int. J. Tiss. Reac. 17: 1-3

Clement, M. V., Hirpara, J. L., Chawdhury, S. H. and Perviz, S. (1998) Chemopreventive agent Resveratrol, a natural product derived from grapes, triggers CD95 signaling-dependent apoptosis in human tumor cells. Blood 92: 996-1002

EIAttor, T. M. and Virji, A. S. (1999) Modulating effect of Resveratrol and quercetin on oral cancer cell growth and proliferation. Anti Cancer Drugs 10: 187-193

Frankel, E. N., Waterhouse, A. L. and Kinsella, J. E. (1993) Inhibition of human LDL oxidation by Resveratrol. The Lancet 341: 1103-1104

Fuhrman, B., Lavy, A. and Aviram, M. (1995) Consumption of red wine with meals reduces the susceptibility of human plasma and low-density lipoprotein to lipid peroxidation. Am. J. Clin. Nutr. 61: 549-554

Goldberg, D. M., Yan, J., Ng, E., Diamandis, E. P., Karumanchiri, A., Soleas, G. and Waterhouse, A. L. (1995) A global survey of trans-Resveratrol concentrations in commercial wines. Am. J. Enol. Viticult. 46: 159-165

Goldberg, D. M., Soleas, G. J., Hahn, S. E., Diamandis, E. P. and Karumachiri, A. Identification and assay of trihydroxystilbenes in wine and their biological properties. In: WineNutritional and therapeutic benefits. Watkins, T.R. (ed.) pp. 2443, Am. Chem. Soc., Washington

Hsieh, Tch. and Wu, J. M. (1999) Differential effects on growth, cell cycle arrest and induction of apoptosis by Resveratrol in human prostate cancer cell lines. Exp. Cell Res. 249: 109115

Huang, C., Ma, Wy., Goranson, A. and Dong, Z. (1999) Resveratrol suppresses cell transformation and induces apoptosis through a p53-dependent pathway. Carcinogenesis 20: $237-242$

Ingham, J. L. (1976) 3,5,4'-Trihydroxystilbene as a phytoalexin from groundnuts (Arachis hypogea). Phytochem. 15: 1791-1793

Jang, M., Cai, L., Udeani, G. O., Slowing, K. V., Thomas, C. F., Beecher, C. W., Fong, H. H., Farnsworth, N. R., Kinghorn, A. D., Mehta, R. G., Moon, R. C. and Pezzuto, J. M. (1997) Cancer chemopreventive activity of Resveratrol, a natural product derived from grapes. Science 275: $218-220$
Kiraly-Veghely, Zs., Tyihák, E., Albert, L., Németh, Zs. and Katay, Gy. (1998) Identification and measurement of Resveratrol and formaldehyde in parts of white and blue grape berries. Acta Biol. Hung. 49: 281-289

Langcake, P. and Pryce, R. J. (1976) The production of Resveratrol by Vitis vinifera and other members of the Vitaceae as a response to infection or injury. Physiol. Plant Pathol. 9: 77-86

Mgbonyevi, O. P., Russo, J. and Russo, L. H. (1988) Antiproliferative effect of synthetic Resveratrol on human breast epithelial cells. Int. J. Oncol. 12: 865-869

Miller, N. J. and Rice-Evans, C. A. (1995) Antioxidant activity of Resveratrol in red wine. Clin. Chem. 41: 1789

Nigdikar, S. V., Williams, N. R., Griffin, B. A. and Howard, A. N. (1998) Consumption of red wine polyphenols reduces the susceptibility of low-density lipoproteins to oxidation in vivo. Am. J. Clin. Nutr. 68: 258-265

Pace-Asciak, C. R., Hahn, S., Diamondis, E. P., Soleas, G. and Goldberg, D. M. (1995) The red wine phenolics transResveratrol and quercetin block human platelet aggregation and eicosanid synthesis. Implications for protection agarost coronary heart disease. Clin. Chim. Acta 235: 207-219

Pendurthi, U. R., Williams, J. T. and Rao, L. V. M. (1999) Resveratrol, a polyphenolic compound found in wine, inhibits tissue factor expression in vascular cells. A possible mechanism for the cardiovascular benefits associated with moderate consumption of wine. Arteroscler. Thromb. Vasc. Biol. 19: 416-426

Romeroperez, A. L., Lamuelaraventos, R. M., Waterhouse, A. L. and Deletorreboronat, M. C. (1996) Levels of cis- and transResveratrol and their glucosides in white and rose Vitis vinifera wines from Spain. J. Agric. Food Chem. 44: 2124-2128

Siemann, E. H. and Creasy, L. L. (1992) Concentration of the phytoalexin Resveratrol in wine. Am. J. Enol. Vitic. 43: 49-52

Soleas, G. J., Diamandis, E. P. and Goldberg, D. M. (1997) Resveratrol: A molecule whose time has come? And gone? Clin. Biochem. 30: 91-113

Szende, B., Tyihák, E., Trézl, L., Szõke, É., László, L., Kátay, Gy. and Király-Véghely, Zs. (1999) Formaldehyde generators and capturers as influencing factors of mitotic and apoptotic processes. Acta Biol. Hung. 49: 323-329

Turrens, J. F., Larisccia, J. and Nair, M. G. (1997) Resveratrol has no effect on lipoprotein profile and does not prevent peroxidation of serum lipids in normal rats. Free Rad. Res. 27: 557-362

Tyihak, E., Albert, L., Nemeth, Zs., Katay, Gy., Kiraly-Veghely, Zs. and Szende, B. (1998) Formaldehyde cycle and the natural formaldehyde generators and capturers. Acta Biol. Hung. 49: 225-238

Uenobe, F., Nakamura, Si. and Miyazawa, M. (1997) Antimutagenic effect of Resveratrol against Trp-P-1. Mut. Res. 373: $197-200$

Wyllie, A. H. (1987) Apoptosis: cell death in tissue regulabon. J. Pathol. 153: 313-316 